HUBERT MAZUR* - KIELCE

\title{
BIBLIOTEKI PARAFIALNE W DEKANACIE KSIĄŻ WIELKI W DRUGIEJ POLOWIE XVIII WIEKU ${ }^{1}$
}

Znaczenie badań nad księgozbiorami parafialnymi determinuje fakt, że stanowią one przyczynek do studiów nad kulturą intelektualną kleru parafialnego. Celem niniejszego artykułu jest przybliżenie zasobów bibliotek parafialnych na terenie dekanatu Książ Wielki w 2 poł. XVIII w., co w dalszej perspektywie oświetlić może stan umysłowy duchowieństwa tejże jednostki administracji kościelnej.

W polskiej historiografii brak jak dotychczas syntezy dziejów bibliotek kościelnych ${ }^{2}$. Ukazało się natomiast sporo prac poświęconych księgozbiorom katedralnym i kolegiackim, a zwłaszcza klasztornym, w mniejszym stopniu prywatnym wyższego duchowieństwa ${ }^{3}$. Najsłabiej przebadane pozostają wciąż biblioteki

* Hubert Mazur - mgr historii, młodszy archiwista w Archiwum Państwowym w Kielcach.

${ }^{1}$ Artykuł ten powstał na bazie pracy magisterskiej H. Mazur, Archiwa i biblioteki parafialne $w$ dekanacie Ksiaż Wielki $w 2$ połowie XVIII w., Kielce 2003, napisanej na seminarium prof. Waldemara Kowalskiego, której maszynopis znajduje się w Archiwum Akademii Świętokrzyskiej w Kielcach.

${ }^{2}$ Lukę tę zaledwie częściowo wypełniają: R. Nir, Biblioteki kościelne [w Polsce, średniowiecze], w: Encyklopedia Katolicka (dalej: EKat) t. 2, Lublin 1976, kol. 505-507; L. Grzebień, Biblioteki kościelne [w Polsce, czasy nowożytne], w: EKat, t.2, kol. 507-510; ani mający jedynie charakter zarysu artykuł H. E. Wyczawskiego, Kościelne zbiory biblioteczne (XVI-XVIII wiek) w: Dzieje Teologii Katolickiej w Polsce (dalej: DTK) t. 2: Od odrodzenia do oświecenia, cz. 1: Teologia humanistyczna, red. M. Rechowicz, Lublin 1975, s. 517-551.

${ }^{3}$ Przykładowo: J. Rył, Biblioteka katedralna w Gnieźnie, „Archiwa, Biblioteki i Muzea Kościelne" (dalej: ABMK), 32 (1976) s. 159-248; 33 (1976) s. 237-298; 36 (1978) s. 211-266; L. Grzebień, Biblioteka biskupa Hieronima Rozrażewskiego (1542-1600), ABMK, 22 (1971) s. 61-168; K. Antosiewicz, Biblioteki zakonu Ducha Świętego w Polsce, ABMK, 41 (1980) s. 351-400; 42 (1981) s. 151-183 i ostatnio J. Gwioździk, Biblioteka panien benedyktynek łacińskich we Lwowie (XVI-XVIII wiek), Katowice 2001; A. Szudrowicz, Biblioteka klasztoru karmelitów w Kcyni, ABMK, 78 (2002) s. 243-274; P. Kardyś, Biblioteka przykolegiacka w Wiślicy (XV-XVIII w.), ABMK, $82(2005)$ s. $83-101$. 
parafialne ${ }^{4}$. Nieliczni autorzy zajmujący się tą problematyką ograniczyli swe badania do interesującego ich terytorium czy księgozbioru. Najobszerniejszą i najnowocześniejszą publikacją tego typu jest praca doktorska ks. Tomasza Moskala poświecona bibliotekom parafialnym archidiakonatu sandomierskiego ${ }^{5}$. Tuż po niej wymienić należy monografię księgozbiorów parafialnych archidiakonatu pomorskiego w XVI-XVIII w., której autorem jest Krzysztof Maciej Kowalski' ${ }^{6}$. Ojciec H. E. Wyczawski natomiast dokonał analizy zasobów bibliotecznych kościołów parafialnych diecezji krakowskiej w oparciu o akta wizytacji bpa Jerzego Radziwiłła przeprowadzonej u schyłku XVI stulecia7. Na szczególną uwagę zasługuje też artykuł ks. Jana Kracika, który scharakteryzował książnice parafialne dekanatu Nowa Góra w XVII-XVIII w. w ramach prowadzonych przez siebie prac nad tą jednostką administracji kościelnej. Autor zajął się m.in. kwestią wzajemnych relacji między księgozbiorami farnymi a osobistymi kleru parafialnego i problemem narastania i topnienia tychże zbiorów ${ }^{8}$. Również źródła wizytacyjne stanowią podstawę pracy Kazimierza Gursztyna o księgozbiorach parafialnych w dekanacie kazimierskim w XVII-XVIII w. ${ }^{9}$ Z kolei praca magisterska Czesława Maciaszka dotyczy książnic diecezji płockiej ${ }^{10}$. Ostatnio natomiast bibliotekami parafialnymi archidiakonatu sądeckiego zajął się Krzysztof Haptaś ${ }^{11}$, archidiakonatu wieluńskiego zaś Sławomir Zabraniak ${ }^{12}$. Poza tym napisano kilka artykułów o pojedynczych księgozbiorach. Julian Nieć scharakteryzował krótko poznaną $\mathrm{z}$ autopsji bibliotekę kościoła parafialnego w Zebrzydowicach ${ }^{13}$. Na podstawie inwentarza książek sporządzonego przy okazji wizytacji dekanalnej z $1781 \mathrm{r}$.

\footnotetext{
${ }^{4}$ Charakter wprowadzający mają artykuły: A. Biernacka, M. Dubiński, Zarys dziejów bibliotek parafialnych w Polsce, ABMK, 73 (2000) s. 9-20; M. T. Zahajkiewicz, Funkcja i znaczenie biblioteki parafialnej i klasztornej, ABMK, 77 (2002) s. 9-17.

${ }^{5}$ T. Moskal, Biblioteki parafialne w archidiakonacie sandomierskim w XVIII wieku, Sandomierz 2005.

${ }^{6}$ K. M. Kowalski, Księgozbiory parafialne archidiakonatu pomorskiego w XVI-XVIII wieku. Studium z dziejów kultury intelektualnej Prus Królewskich, Gdańsk 1993.

${ }^{7}$ H. E. Wyczawski, Biblioteki parafialne $w$ diecezji krakowskiej u schyłku XVI w., „Polonia Sacra", 6 (1953/1954) z. 2, s. 114-142; 7 (1955) z. 1, s. 27-68; z. 2, s. 159-173.

${ }^{8}$ J. Kracik, Biblioteki parafialne a prywatne księgozbiory duchowieństwa. Dekanat Nowa Góra w XVII-XVIII w., ABMK, 32 (1976) s. 248-271.

${ }^{9}$ K. Gursztyn, Biblioteki parafialne $w$ dekanacie kazimierskim $w$ XVII-XVIII w., ,,Sprawozdania Towarzystwa Naukowego KUL”, 14 (1965) s. 211-213 i maszynopis tej pracy w Zakładzie Historii KUL. Na pracy tej opiera swe rozważania S. Litak, Struktura i funkcje parafii w Polsce od końca XVI-XVIII w., w: Kościót w Polsce, red. J. Kłoczowski, t. 2, Kraków 1969, s. 363-367.

${ }^{10} \mathrm{C}$. Maciaszek, Biblioteki parafialne diecezji płockiej na przełomie XVI i XVII w., „,Roczniki Teologiczno-Kanoniczne", 25 (1978) z. 1, s. 60.

${ }^{11} \mathrm{~K}$. Haptaś, Dzieła polskich autorów w bibliotekach parafialnych archidiakonatu sqdeckiego w końcu XVI w., ABMK 80, (2003) s. 50-55; Tenże, Literatura o treści świeckiej w bibliotekach parafialnych archidiakonatu sqdeckiego (koniec XVI wieku) ABMK, 82 (2004) s. 79-83.

${ }^{12} \mathrm{~S}$. Zabraniak, Biblioteki kościelne $w$ archidiakonacie wieluńskim $w$ świetle wizytacji XVIXVIII w., ABMK, 84 (2005) s. 361-372.

13 J. Nieć, Biblioteka kościoła parafialnego w Zebrzydowicach koło Krakowa, „Przegląd Biblioteczny" (dalej: PB) 13 (1939) z. 1, s. 28-29.
} 
Jolanta Marszalska omówiła zasób księgozbioru świątyni farnej w Czchowie ${ }^{14}$. Wiktor Bazielich opracował resztki biblioteki nieznanej proweniencji (nazwanej przez siebie umownie parafialna) odkrytej na stryszku starosądeckiego kościoła ${ }^{15}$. Analizą niewielkiego zbioru książek w parafii Bieliny na podstawie akt wizytacji z 1738 r. zajął się Ryszard Skrzyniarz ${ }^{16}$. Nieco informacji na temat księgozbiorów podano także na marginesach monografii poszczególnych parafii ${ }^{17}$. Szczególnie dokładnie omówił zasób librarii kościoła parafialnego w Jędrzejowie Waldemar Kowalski. Podał on także nieco informacji na temat tego typu książnic $\mathrm{w}$ innych parafiach dekanatu jędrzejowskiego, opierając się przy tym o siedemnastowieczne i osiemnastowieczne protokoły powizytacyjne ${ }^{18}$. Istotne znaczenie ma także artykuł Dariusza Główki poświęcony księgozbiorom prywatnym duchowieństwa płockiego ${ }^{19}$.

Słów kilka należy poświęcić historii dekanatu Książ Wielki, tym bardziej, że wspomniana jednostka administracji kościelnej nie doczekała się jak dotychczas osobnego opracowania ${ }^{20}$. Istniała ona już w latach dwudziestych XIV wieku, a jej stolicą była Pałecznica ${ }^{21}$. Dekanat pałecznicki powstał zapewne znacznie wcześniej, prawdopodobnie przed 1173 rokiem, kiedy to w diecezji krakowskiej z inicjatywy bpa Gedki przeprowadzono reformę administracyjną ${ }^{22}$. W ciagu kolejnych wieków stolica i nazwa dekanatu wielokrotnie się zmieniała, a dokładna chronologia tych zmian trudna jest dziś do uchwycenia. Niemniej jednak wiadomo, że od 1340 r. w źródłach występuję już dekanat Wrocimowice ${ }^{23}$, zaś w latach siedemdziesiątych XIV w. Książ Wielki ${ }^{24}$. W połowie XV stulecia kontynuacją jego był dekanat Pałecznica alias Słaboszów ${ }^{25}$. W 1529 r. pojawia się znów deka-

${ }^{14}$ J. Marszalska, Zarys dziejów biblioteki parafialnej w Czchowie, ABMK, 74 (2000) s. 415-418.

${ }^{15}$ W. Bazielich, Resztki bibliotek parafialnej w Starym Saczu, „Roczniki Biblioteczne” (dalej:

RB) 6 (1962) z. 3-4, s. 147-170.

${ }^{16}$ R. Skrzyniarz, Księgozbiór parafialny w Bielinach wedtug wizytacji z 1738 roku, ABMK, 74 (2000) s. 415-418.

${ }^{17}$ Przykładowo: E. Kula, Wieś i parafia Sancygniów, Tuchów 2002, s. 311-314; D. Olszewski, E. Wiśniowski, Parafia Kije. Zarys dziejów, Kielce 1993, s. 70-76; S. Piątkowski, A. Szymanek, Parafia podwyższenia Krzyża Świętego w Zwoleniu, Zwoleń 2002, s. 129-134.

${ }^{18}$ W. Kowalski, D. Olszewski, Parafia Trójcy Św. w Jędrzejowie na tle dekanatu. Zarys dziejów, Kielce 2002, s. 95-210.

${ }^{19}$ D. Główka, Księgozbiory duchowieństwa płockiego w XVIII w., „Kwartalnik Historyczny”, 102 (1995) nr 2, s. 15-26.

${ }^{20}$ Nieco informacji na temat poszczególnych parafii podał J. Wiśniewski, Dekanat miechowski, Radom 1917.

${ }^{21}$ J. Dudziak, Dziesięcina papieska w Polsce średniowiecznej, Lublin 1974, s. 130.

22 J. Chachaj, Pierwotna średniowieczna sieć dekanalna $w$ diecezji krakowskiej, ABMK, 71 (1999) s. 377-387.

${ }^{23}$ T. Ładogórski, Studia nad zaludnieniem Polski w XIV w., Wrocław 1958, s. 197-198.

${ }^{24}$ B. Kumor, Dzieje diecezji krakowskiej do roku 1795, t. 4, Kraków 2002, s. 147.

25 J. Długosz, Liber beneficiorum dioecesis Cracoviensis, wyd. A. Przeździecki, t. 2, Opera omnia, t. 8, Kraków 1863-1864, s. 74-102. 
nat Wrocimowice ${ }^{26}$. Utrzymał się on przez całe XVI i XVII stulecie ${ }^{27}$, a zniesiony został dopiero w 1711 roku przez prymasa Stanisława Szembeka, który w jego miejsce powołał nowy ze stolicą w Książu Wielkim ${ }^{28}$. W roku 1772 dekanat o powierzchni $620 \mathrm{~km}^{2}$ zajmował $5 \%$ terytorium archidiakonatu krakowskiego ${ }^{29}$. W 1783 dekanat ksiąski graniczył od południa z dek. proszowickim, od zachodu z dek skalskim, od północy z dek. jędrzejowskim, z którymi wspólnie przynależał do archidiakonatu krakowskiego, od wschodu zaś z dek Sokolina położonym już w prepozyturze wiślickiej. W tym czasie ,dtugość jego rozciaga[ła] się na mil trzy, szerokość na mil dwie”. Dekanat zamykał w sobie 15 kościołów farnych: Radziemice, Łętkowice, Nasiechowice, Sławice, Mstyczów, Kozłów, Książ Wielki, Kalinę, Racławice, Zielenice, Wrocimowice, Pałecznicę, Małoszów, Słaboszów i Książ Mały, a także , klasztor męski konwent formalny i fare majacy w Miechowie jeden, mniejszy dwunastu zakonników majacy w Ksiażu Wielkim”. Dodać warto, że dziekanem ksiąskim był, od 1779 roku, pleban zielenicki Wiktoryn Gostyński ${ }^{30}$. Sieć parafialna na omawianym obszarze ukształtowała się w całości jeszcze w średniowieczu, przy czym najstarszym ośrodkiem oddziaływania parafialnego kleru był Miechów ${ }^{31}$, najpóźniej zaś, bo przed połową XV w., erygowano fary w Małoszowie, Radziemicach i Kozłowie ${ }^{32}$. Jeśli chodzi o stosunki demograficzne i religijne w latach osiemdziesiątych XVIII w., to dekanat ksiąski zamieszkiwało 20038 osób, przy czym 97\% ludności stanowili katolicy, 3\% zaś starozakonni ${ }^{33}$. Zupełny brak surowców naturalnych spowodował, że na omawianym obszarze nie rozwinął się przemysł, a głównym zajęciem ludności wiejskiej było rolnictwo ${ }^{34}$. Mieszkańcy miast zajmowali się ponadto rzemiosłem oraz drobnym, lokalnym handlem ${ }^{35}$, gdyż poważniejsza wymiana nie mogła się tu odbywać ze względu na znaczne oddalenie Miechowa i Książa Wielkiego od głównych szlaków handlowych ${ }^{36}$. Oba miasta nie pełniły też żadnych ważnych funkcji

${ }^{26}$ Księga dochodów beneficjów diecezji krakowskiej z roku 1529 (tzw. Liber retaxationum) wyd. Z. Leszczyńska-Skrętowa, Wrocław-Warszawa-Kraków 1968, passim.

${ }^{27}$ Kumor, Dzieje diecezji, t. 4, s. 26.

${ }^{28}$ E. Madejski, Kościót parafialny św. Wojciecha w Ksiażu Wielkim, Książ Wielki 1999, s. 103.

${ }^{29}$ S. Litak, Kościót taciński w Polsce okoto 1772 r. Mapa. Komentarz. Indeks, Rzym-Lublin 1991, s. 63.

${ }^{30}$ Archiwum Kurii Metropolitalnej w Krakowie (dalej: AKMKr) Acta Visitationis 54 (dalej: AV 54) s. 233.

${ }^{31}$ Z. Pęckowski, Miechów. Studia z dziejów miasta i ziemi miechowskiej do 1914 roku, Kraków 1967.

${ }^{32}$ Daty erekcji poszczególnych parafii podaje między innymi B. Kumor, Dzieje diecezji, t. 4, s. $195-232$.

${ }^{33}$ AKMKr, AV 54, s. 233, 245, 252-253, 265, 274, 294, 306, 341, 361, 370, 377, 386, 397, 406, 412, 425; zob. też Spis ludności diecezji krakowskiej prymasa M. J. Poniatowskiego z 1787 roku, wyd. B. Kumor, ABMK, 35 (1978) s. 367-370.

${ }^{34} \mathrm{H}$. Madurowicz, A. Podraza, Regiony gospodarcze w Matopolsce Zachodniej w drugiej połowie XVIII wieku, Wrocław 1958, s. 94-124.

${ }^{35}$ Pęckowski, Miechów, s. 93-140.

${ }^{36}$ B. Wyrozumska, Drogi w ziemi krakowskiej do końca XVI w., Wrocław 1977, s. 66-67. 
politycznych w życiu kraju czy województwa. Książ Wielki był jedynie stolicą powiatu.

Podstawę źródłową prezentowanego artykułu stanowią akta wizytacji trzech dekanatów: proszowickiego, ksiąskiegoijędrzejowskiego przeprowadzonej w 1783 r. przez kanonika sandomierskiego ks. Jacka Kochańskiego z polecenia ówczesnego administratora diecezji krakowskiej arcybiskupa Michała Poniatowskiego, przechowywane obecnie w Archiwum Kurii Metropolitalnej w Krakowie. Zawierają one opisy majątku ruchomego i nieruchomego poszczególnych kościołów, w tym inwentarze książek oraz spisy dokumentów. Ogromne znaczenie i wysoka wartość poznawcza akt wizytacji jako źródeł historycznych dowiedziona została już wielokrotnie, w tym przede wszystkim przez Stanisława Litaka ${ }^{37}$.

Inwentarze parafialnych księgozbiorów zawarte $\mathrm{w}$ aktach wizytacji zawierają bardzo niedokładne i skrócone opisy dzieł, ograniczone do podania autora i tytułu dzieła, a często tylko jednego z tych elementów (np. Martinus Bonacina; Strumień Zbawienny) pozbawione są informacji o miejscu i roku wydania ${ }^{38}$. Nierzadko notariusz wizytacyjny poprzestawał na zanotowaniu książki pod jej skróconym, obiegowym, a przez to trudnym dziś do rozszyfrowania tytułem. Niekiedy już sam wizytator miał problem z ustaleniem tytułu i autora dzieła (zwłaszcza, gdy było ono zniszczone) i sygnalizował je np. w taki oto sposób Ksiażka włoska. Wobec tak nieprecyzyjnych i lakonicznych zapisów znacznie utrudniona była identyfikacja dzieł polegająca na ustaleniu autora, dokładnego tytułu oraz roku i miejsca wydania. W tych żmudnych i pracochłonnych badaniach pomocne okazały się przede wszystkim prace Karola Estreichera ${ }^{39}$ i Hugo Hurtera ${ }^{40}$, a także (zwłaszcza do ustalania danych biograficznych autorów) Słownik Polskich Teologów Katolickich ${ }^{41}$ i Podręczna Encyklopedia Kościelna ${ }^{42}$ oraz inne wydawnictwa ${ }^{43}$. Wymienione wyżej pozycje umożliwiły także przeprowadzenie klasyfikacji gatunkowej poszczególnych tytułów.

${ }^{37} \mathrm{~S}$. Litak, Akta wizytacyjne parafii z XVI-XVIII w jako źródło historyczne, „Zeszyty Naukowe KUL", 5 (1962) nr 3, s. 41-58; Tenże, Wstęp, w: Akta wizytacji generalnej diecezji inflanckiej i kurlandzkiej czyli piltyńskiej z 1761 roku, wyd. S. Litak, Toruń 1998.

${ }^{38}$ K. Rulka, Stan badań nad księgozbiorami diecezji włocławskiej oraz postulaty badawcze na przyszłość, ABMK, 26 (1973) s. 34-35.

${ }^{39}$ K. Estreicher, Bibliografia polska XVI-XVIII wieku, cz. 3, t. 1-33, Kraków 1891-1939.

${ }^{40}$ H. Hurter, Nomenclator litterarius theologiae catholicae, t. 1-4, Oeniponti 1903-1913.

${ }^{41}$ Stownik Polskich Teologów Katolickich (dalej: SPTK), red. H. E. Wyczawski, t. 1-4, Warszawa 1981-1983.

${ }^{42}$ Podręczna Encyklopedia Kościelna (dalej: PEK) t. 1-44, wyd. Z. Chełmnicki i in., Warszawa 1904-1916.

${ }^{43}$ Nowy Korbut. Bibliografia Literatury Polskiej. Piśmiennictwo Staropolskie (dalej: NK) oprac. zespół pod kierunkiem R. Pollaka, t. 1-3, Warszawa 1963-1965; Lexicon für Theologie und Kirche (dalej: LTK) hrsg., von W. Kasper, b. 1-9, Freiburg-Basel 1993-2000; Encyklopedia kościelna podtug teologicznej encyklopedii Weltzera $i$ Weltego z licznymi jej dopetnieniami, przy wspótpracownictwie kilkunastu duchownych i świeckich osób wydana przez ks. Nowodworskiego (dalej: EK) t. 1-33, Warszawa-Włocławek 1873-1933; J. Pelczar, Zarys dziejów kaznodziejstwa, t. 1-3, Kraków 1896-1900; a dla druków autorów starożytnych także Słownik Pisarzy Antycznych, red. A. Świderkówna (dalej: SPA) Warszawa 1982. 
W aktach wizytacji dekanatu Książ Wielki biskupa Michała Poniatowskiego we wszystkich parafiach odnotowane zostało istnienie mniejszych lub większych księgozbiorów. Źródło to informuje jednak wyłącznie o bibliotekach instytucjonalnych, pomija zaś całkowitym milczeniem ewentualne prywatne zbiory duchowieństwa.

Podstawę parafialnych księgozbiorów stanowiły księgi służące liturgii. Jak wynika z tabeli nr 1 u schyłku XVIII stulecia wszystkie parafie na terenie dekanatu Książ Wielki były zaopatrzone w księgi liturgiczne, pośród których czołowe miejsce zajmował mszał, znajdujący się w każdym kościele i to zwykle w większej ilości egzemplarzy. Obok zwykłego mszału dużą częstotliwością występowania odznaczają się mszaliki żałobne (rekwialne, relikwialne, pogrzebowe). Także agendy i ewangeliarze pojawiły się niemal we wszystkich kościołach. Nie wszystkie parafie posiadały graduały, antyfonarze, psałterze. Natomiast brewiarze i procesjonały występowały jedynie sporadycznie ${ }^{44}$. Na podstawie akt wizytacji z 1783 r. niewiele można powiedzieć na temat poszczególnych egzemplarzy ksiąg liturgicznych zgromadzonych w kościołach. Notariusz wizytacyjny pozostawił jedynie informacje o stanie i wieku niektórych z nich, o stopniu ich zniszczenia, czasem też o dokonanych naprawach (albo o konieczności ich przeprowadzenia) a niekiedy również o ich oprawach ${ }^{45}$. Spotykane niemal w każdym opisie sformułowania ,stary" nie pozwalają dociec czy mowa o dawnych wydaniach ksiag, czy o stanie ich zachowania. Przypuszczać jedynie można, że znakomita większość tych ksiag była zreformowana i wprowadzała rytuał rzymski ${ }^{46}$.

Księgi liturgiczne nie tworzyły jeszcze w zasadzie biblioteki ${ }^{47}$. Na nią składały się mianowicie książki pomocnicze, służące plebanom do nauczania wiernych i podnoszenia poziomu własnego wykształcenia. One to właśnie stanowią druga grupę ksiag, o których informują protokoły wizytacyjne z 1783 roku. Takie księgozbiory istniały u schyłku XVIII stulecia w jedenastu kościołach $(68 \%)^{48}$ dekanatu Książ Wielki: w Radziemicach, Łętkowicach, Nasiechowicach, Sławicach, Mstyczowie, Kozłowie, Książu Wielkim, Miechowie, Kalinie, Słaboszowie i Książu Małym ${ }^{49}$, przy czym tylko w Mstyczowie książki te zostały wyraźnie

${ }^{44}$ AKMKr, AV 54, s. 238-239, 249, 256-257, 267-268, 279, 298, 314-315, 353, 365, 372, 380, 402, 409, 417, 429-430.

${ }^{45}$ Przykładowo w Mstyczowie, AKMKr, AV 54, s. 279: „Mszałów nowo oprawnych cztery”; w Racławicach, AKMKr, AV 54, s. 300: „Agendka nadpsuta jedna”; w Miechowie, AKMKr, AV 54, s. 353: „Mszał cały w srebro oprawny jeden, [...] mszał stary w aksamit oprawny jeden”; w Nasiechowicach, AKMKr, AV 54, s. 256: „Agendka mała świeżo zreperowana jedna”.

${ }^{46}$ Por. Kowalski, Olszewski, Parafia Św. Trójcy, s. 95.

${ }^{47}$ Rulka, Stan badań, s. 33.

${ }^{48}$ Wielkości te znacznie przewyższały więc zrelacjonowane dla dekanatu jędrzejowskiego w 1783 roku (43,5\%) całego archidiakonatu krakowskiego w 1. 1747-1748 (41,1\%) archidiakonatu pomorskiego w 1. 1745-1746 (14,3\%) oraz diecezji płockiej w latach 1775-1776 (21\%). Poniższe ustalenia oparto o Kowalski, Olszewski, Parafia Św. Trójcy, s. 9; Kracik, Biblioteki parafialne, s 259; K. M. Kowalski, Księgozbiory parafialne, s. 21-23; Główka, Księgozbiory duchowieństwa, s. 19.

${ }^{49}$ AKMKr, AV 54, s. 238-239, 249, 256-257, 267-268, 279, 298, 314-315, 353, 365, 417, $429,430$. 
wyodrębnione jako ,księgi biblioteczne" ${ }^{50}$. W inwentarzach bibliotecznych pozostałych parafii nie zastosowano żadnych podziałów pośród książek. Jedynie w Radziemicach, Nasiechowicach i Sławicach uporządkowano książki według formatów (in folio, in quarto, in octavo) ${ }^{51}$. Należy pamiętać również, że w okresie wczesnonowożytnym wciąż silna była tradycja wspólnego traktowania obu pokrewnych odmian zbiorów, jakimi były biblioteki i archiwa. Nie dostrzegano też miedzy nimi większej różnicy ${ }^{52}$. Stąd też w dobie przedrozbiorowej do biblioteki oprócz książek zaliczano księgi metrykalne i albumy brackie, podczas gdy przez pojęcie archiwum rozumiano raczej zbiór luźnych dokumentów i ich kopii oraz sumariuszy $^{53}$.

W zakresie liczby kościołów posiadających biblioteki w drugiej połowie XVIII wieku nastapił istotny, bo niemal trzykrotny wzrost, w stosunku do stanu, jaki istniał u schyłku 1 połowy tegoż stulecia. Liczba książek w całym dekanacie zwiększyła się natomiast przeszło dwunastokrotnie ${ }^{54}$. Dodać też trzeba, że sytuacja z 1 połowy XVIII nie różniła się zbytnio od tej, jaką zastała wizytacja radziwiłłowska u schyłku XVI w., kiedy to w ówczesnym dekanacie Wrocimowice bibliotekami instytucjonalnymi dysponowały parafie w Nasiechowicach (20-30 książek) Słaboszowie i Książu Wielkim $(86)^{55}$.

Liczba książek w poszczególnych świątyniach przedstawia się bardzo nierównomiernie. Liczebność poszczególnych księgozbiorów ilustruje tabela 2. Najwięcej pozycji znajdowało się w Książu Wielkim - 98 i w Książu Małym - 91. Pokaźny był księgozbiór w Radziemicach liczący 47 woluminów. Najsłabiej prezentowała się libraria w Kozłowie, gdzie odnotowano tylko cztery druki.

Średnia wielkość parafialnego księgozbioru w dekanacie Książ Wielki wynosi zatem 20,93 książki ${ }^{56}$.

Obok książnic parafialnych na terenie dekanatu Książ Wielki istniały także dwie biblioteki klasztorne. Niestety akta wizytacji Poniatowskiego nie odnotowały z ilu dzieł składała się libraria klasztoru bożogrobców w Miechowie, bowiem wizytator ze względu na jej nieuporządkowanie, a zapewne także przez własne lenistwo, poprzestał jedynie na wyliczeniu 14 mszałów i 5 mszalików rekwialnych $^{57}$. Z innych źródeł jednak wiadomo, że miechowski księgozbiór klasztorny był pokaźny. Istnieją różne opinie co do jego wielkości. Zapewne biblioteka ta mogła liczyć ok. 10 tys. woluminów ${ }^{58}$. Drugi księgozbiór klasztorny, liczący z gó-

\footnotetext{
${ }^{50}$ Tamże, s. 279.

${ }^{51}$ Tamże, s. 238-239, 256-257, 267-268.

${ }^{52}$ S. Librowski, Archiwa, biblioteki i muzea kościelne. Podobieństwa i różnice. Próba rozgraniczenia, ABMK, 16 (1968) s. 5-18.

${ }^{53}$ Piątkowski, Szymanek, Parafia podwyższenia, s. 130.

${ }^{54} \mathrm{~W}$ latach $1747-48$ tylko przy czterech kościołach farnych (a było ich wtedy 15 ) istniały księgozbiory (łącznie liczące 26 pozycji) zob. Kracik, Biblioteki parafialne, s. 259.

${ }^{55}$ Wyczawski, Biblioteki parafialne, s. 134-135, 137.

${ }^{56} \mathrm{~W}$ statystyce tej pominięto miechowski księgozbiór, który miał charakter biblioteki klasztornej.

${ }^{57}$ AKMKr, AV 54, s. 353: „biblioteki miejscowej opisania wymaga to miejsce, ale że nie jest ułożona do przyszłej wizyty opisanie onej zawiesza się i przygotowanie naznacza".

${ }^{58}$ Szerzej zob. R. Skrzyniarz, Księgozbiór historyczny bożogrobców w parafii Miechów, ABMK,
} 
rą 50 woluminów funkcjonował przy zakonie augustianów w Książu Wielkim ${ }^{59}$. Cechą charakterystyczną opisu inwentarza bibliotecznego tegoż klasztoru jest fakt, że notariusz wizytacyjny zanotował niemal wyłącznie nazwiska autorów, pomijają całkowicie tytuły, książek tworzących ten księgozbiór.

Zdziwienie może budzić fakt, że tylko część kościołów posiadała księgozbiory, podczas gdy potrzeby duchowieństwa wszędzie były takie same. Stan ten można ewentualnie thumaczyć niedbalstwem i niekonsekwencją wizytatora, który po prostu nie włączył inwentarzy bibliotecznych do protokołów wizytacyjnych. Nigdzie, bowiem brak biblioteki nie został stwierdzony wprost. Ponieważ jednak akta wizytacji osiemnastowiecznych są na ogół bardzo szczegółowe i dokładne, toteż wydaje się bardziej prawdopodobne, że w niektórych parafiach bibliotek rzeczywiście nie było. Domyślać się jedynie można, że pierwszoplanowe znaczenie mogły mieć pominięte przez źródła księgozbiory osobiste.

Najciekawszą i najistotniejszą kwestią w badaniach nad księgozbiorami jest ich zawartość. W bibliotekach kościelnych, w tym również w parafialnych znajdowała sięprzede wszystkim literatura teologiczna. Jak wynika ztabelinr 3 w Książu Wielkim stanowiła ona ponad $80 \%$ zgromadzonych dzieł. Literatura świecka (nauka i literatura piękna) to niespełna $8 \%$ wszystkich pozycji. Można się więc pokusić o stwierdzenie, że stanowiła ona niejako suplement do dzieł religijnych. 10,5\% tytułów nie udało się zidentyfikować, a co za tym idzie nie ma możliwości przeprowadzenia ich klasyfikacji gatunkowej.

Pośród literatury teologicznej wyodrębnić można wiele różnych działów. W niniejszej pracy zasoby treściowe omówione zostaną w następujących grupach tematycznych: pomoce homiletyczne, teologia pastoralna, teologia moralna, teologia ascetyczna, teologia polemiczno-dogmatyczna, biblistyka, historia Kościoła i żywoty świętych, prawo kanoniczne, pisma Ojców Kościoła, liturgia. Wielotematyczność i niejednolity charakter niektórych pozycji utrudniły klasyfikację gatunkową ${ }^{60}$. Niemniej jednak poniższe ustalenia i wyliczenia zawarte w tabeli $\mathrm{nr} 4$ oddają w dużej mierze faktyczny stan rzeczy.

Ponieważ jednym z najważniejszych obowiązków kleru parafialnego było przynajmniej cotygodniowe głoszenie kazań, stąd też najwięcej, bo blisko $40 \%$ dzieł w księgozbiorach parafialnych na terenie dekanatu Książ Wielki to pomoce homiletyczne ${ }^{61}$. $Z$ tego powodu należy się im więc najwięcej uwagi.

$\mathrm{Z}$ polskich autorów kazań największą popularnością cieszył się małopolski reformat, mariolog i polemista Antoni Węgrzynowicz (1658-1721). Jego kazania pojawiają się aż dziewięć razy w spisach wizytacyjnych dekanatu Książ Wielki ${ }^{62}$.

77 (2000) s. 74-75; E. Truskolaska, Księgozbiór bożogrobców miechowskich $w$ Bibliotece Uniwersytetu Warszawskiego, ABMK, 81 (2004) s. 353-369.

${ }^{59}$ Szerzej zob. E. Madejski, Klasztor augustianów w Ksiqż̇u Wielkim, „Analecta Cracoviensia”, 21-22 (1989/90).

${ }^{60}$ Problemy te są typowe dla badań nad dawnymi księgozbiorami, zob. J. Kracik, Biblioteki parafialne, s. 260; Grzebień, Biblioteka biskupa, s. 95.

${ }^{61}$ Szerzej o tej dyscyplinie teologii zob. M. Brzozowski, Teoria kaznodziejstwa (wiek XVIXVIII), DTK, t. 2, cz. 1, s.

${ }^{62}$ Były to: Melodia św. Kazimierza, Kraków 1704; Nuptiae Agni, gody baranka..., Kraków 1711; 
Dosyć często zaglądano do kaznodziejskiej spuścizny kanonika krakowskiego, polihistora i encyklopedysty Szymona Starowolskiego (1588-1656). Ogółem kazania Starowolskiego odnotowano w siedmiu parafiach ${ }^{63}$. Cztery parafie posiadały dzieła jego naśladowcy, wybitnego teologa i moralisty, profesora Akademii Krakowskiej i kanonika katedry wawelskiej Szymona Makowskiego $(\uparrow 1683)^{64}$. Poczytną pozycją z zakresu homiletyki było także Dzieło zbawienia ludzkiego, którego autorem był franciszkanin Antoni Stefanowicz ${ }^{65}$. Czterokrotnie odnotowano kaznodziejskie prace małopolskiego franciszkanina konwentualnego, znawcy Pisma Świętego i Ojców Kościoła Waleriana Gutowskiego (1629-1693) ${ }^{66}$. Do rozpowszechnionych w dekanacie Książ Wielki należały również utwory małopolskiego reformata, kaznodziei i polemisty Franciszka Rychłowskiego (1618$1680)^{67}$, napotkane w trzech bibliotekach. Także trzykrotnie odnotowano, mające charakter traktatów mariologicznych i chrystologicznych kazania Jacka Liberiusza (1599-1673) kanonika regularnego laterańskego, profesora Akademii Krakowskiej ${ }^{68}$. Dwie parafie poszczycić się mogły dziełami dominikanina Fabiana Birkowskiego (1566-1636) hagiografa, patrologa, nadwornego kaznodziei królewicza Władysława Wazy, wybitnego mówcy nazywanego ,chryzologiem sarmackim", uznawanego za następcę Skargi ${ }^{69}$. Do przygotowania kazań okolicznościowych plebanom w Nasiechowicach i Książu Małym służył Orator polityczny czyli mowy weselne i pogrzebowe Kazimierza Jana Wojsznarowicza $(\dagger 1680)$ kanonika wileńskiego i sekretarza królewskiego ${ }^{70}$. W indeksie ksiąg parafii Książ Mały widnieją dwie pozycje autorstwa jezuity Szczepana Ponińskiego (1656-1733) kaznodziei trybunału piotrkowskiego ${ }^{71}$. Kanonik kolegiaty św. Floriana w Krakowie

Kazań niedzielnych księa pierwsza to jest siedm trab..., Częstochowa 1713; Alphabetum Immaculatae Conceptionis SS. Virgis Mariae, Kraków 1710; zob. SPTK, t. 4, s. 412-414.

${ }^{63} \mathrm{Z}$ czego najważniejsze zbiory kazań to: Świqtnica Pańska zamykajqca w sobie kazania na uroczystości świat całego roku, Kraków 1645; Arka Testamentu zamykajaca w sobie kazania niedzielne całego roku, Kraków 1645-1649; Wieniec niewiędnacy Przeczystej Panny Marii zamykajacy w sobie kazania na wszystkie jej święta doroczne..., Kraków 1649; SPTK, t. 4, s. 187-193.

${ }^{64}$ Conciones (na który składały się Pars hiemalis concionum dominicalium..., Pars hiemalis concionum pro festivitatibus..., Pars aestiva concionum dominicalium..., oraz Pars aestiva concionum pro fesivitatibus...) wydanego w Krakowie w latach 1665-1675; zob. W. Wicher, Szymon Stanisław Makowski teolog moralista polski z XVII w., Kielce 1926, passim.

${ }^{65}$ Dzieło zbawienia ludzkiego, Kraków 1678. J. Pelczar, Zarys dziejów, t. 2, s. 233 wymienia tylko jego kazania nie podając jakichkolwiek informacji na temat autora; podobnie K. Estreicher, Bibliografia polska, t. 29, s. 270.

${ }^{66}$ Quadrajezymat cały albo kazania w polskim języku ..., Kraków 1668; zob. SPTK, t. 1, s. $612-$ $-613$.

${ }^{67}$ Kazania na niedziele całego roku, Kraków 1664; Kazania na święta całego roku, Kraków 1657; zob. SPTK, t. 3, s. 535-537.

${ }^{68}$ Gwiazda Morska, Kraków 1670; Gospodarz nieba i ziemi Jezus Chrystus, Kraków 1669; zob. SPTK, t. 2, s. 524-525.

${ }^{69}$ Kazania na niedziele i święta doroczne, Kraków 1620-1628; zob. SPTK, t. 1, s. 163-165.

${ }^{70}$ Orator polityczny czyli mowy weselne i pogrzebowe, Kraków 1648; zob. NK, t. 3, s. 413.

${ }^{71}$ Są to: Król nieba i ziemi Chrystus kazaniami na uroczyste święta wystawiony, Poznań 1725; 
i profesor Akademii Krakowskiej Sebastian Fabian Stryjewicz (1621-1681) ${ }^{72}$ i Stanisław Szczepanowski ${ }^{73}$ byli reprezentowani swoimi kazaniami w dwóch parafiach. W tym swoistym rankingu najbardziej poczytnych polskich autorów kazań tylko dwunastu pojawia się więcej niż jeden raz w aktach wizytacji. Pozostali reprezentowani są tylko pojedynczymi egzemplarzami swych dzieł. Listę tychże autorów otwierają jezuici Stanisław Bielicki (XVII/XVIII w.) $)^{74}$ i Jan Kraszewski $(1631-1708)^{75}$, cysters z Mogiły Gabriel Markiewicz (XVII w. ${ }^{76}$, kanonik krakowski, profesor i rektor Akademii Krakowskiej Sebastian Piskorski $(\dagger 1707)^{77}$, wierszopis i historyk, pijar Idzi Madeyski (1691-1746) ${ }^{78}$. Tylko pleban z Książa Wielkiego dysponował pracami dwóch polskich kaznodziejów okresu zygmuntowskiego jezuity, thumacza, teologa polemisty Jakuba Wujka (1541-1597) ${ }^{79}$ i najwybitniejszego polskiego mówcy Piotra Skargi ${ }^{80}$. Z innych polskich autorów kazań wymienić jeszcze wypada: jezuitę Jana Wolskiego (1659-1729) ${ }^{81}$, Jana Franciszka Włockiego pijara od św. Józefa ${ }^{82}$, jezuitę Franciszka Kowalickiego $(1668-1731)^{83}$, trynitarza, kaznodzieję i historyka zakonu Onufrego od Najświętszego Sakramentu († 2 poł. XVIII w. $)^{84}$, kanonika kolegiat w Krakowie i Bobowej, kanonistę, profesora Akademii Krakowskiej ks. Klemensa Herkę $(1713-1754)^{85}$, archidiakona poznańskiego Wilhelma Robertsona $(\dagger 1754)^{86}$, rek-

oraz Król Bolesny Chrystus Zbawiciel ..., Poznań 1723; zob. K. Estreicher, Bibliografia polska, t. 25, s. 56-57; PEK, t. 31-32, s. 322.

${ }^{72}$ Kazania na święta uroczyste Pana Zbawiciela Naszego, Najświętszej Marii Panny i Świetych Pańskich, Kraków 1680; zob. SPTK, t. 4, s. 218-219.

${ }^{73}$ Kazania niedzielne na caly rok, Kraków 1761; Kazania świqtalne na cały rok..., Kraków 1672; zob. Estreicher, Bibliografia polska, t. 19, s. 216.

${ }^{74}$ Niedziele kaznodziejskie..., Częstochowa 1712; zob. Pelczar, Zarys dziejów, t. 2, s. 238; PEK, t. $3-4$, s. 374 .

${ }^{75}$ Impetus bonarum cogitationum ex Evangelis dominicanum totius anni desumpti, Kalisz 1696; zob. SPTK, t. 2, s. 415.

${ }^{76}$ Lutnia wdzięcznie brzmiqca, Kraków 1695; zob. SPTK, t. 3, s. 67.

${ }^{77}$ Kazania na dni pańskie, Kraków 1706; zob. SPTK, t. 3, s. 374; Pelczar, Zarys dziejów, t. 2, s. 231.

${ }^{78}$ Rok kaznodziejski albo kazania na niedziele całego roku, Kraków 1741; zob. EK, t. 13, s. 22; Pelczar, Zarys dziejów, t. 2, s. 254.

${ }^{79}$ Postylla katoliczna, Kraków 1573-1575; Postylla katoliczna mniejsza, Kraków 1579-1580; zob. NK, t. 3, s. 419-424.

${ }^{80}$ Kazania na niedziele i święta całego roku, Kraków 1595; zob. NK, t. 3, s. 236-245.

${ }^{81}$ Dni Pańskie Stońcem Boskiego Stowa wypogodzone. To jest kazania niedzielne całego roku, Częstochowa 1714; zob. Estreicher, Bibliografia polska, t. 33, s. 295.

${ }^{82}$ Kazania tak $w$ różnych publikach tak i ordynaryjne, Kraków 1741; zob. Pelczar, Zarys dziejów, t. 2, s. 248.

${ }^{83}$ Katedra kaznodziei niedzielnego na caly rok, Sandomierz 1725; zob. NK, t. 2, s. 403.

${ }^{84}$ Różeczka Aronowa Najjaśniejsza Nieba i Ziemi Królowa Maria Panna kazaniami wystawiona, Wilno 1732; zob. J. Pelczar, Zarys dziejów, t. 2, s. 257.

${ }^{85}$ Zabawy przy akademicznych pracach... to jest kazania niektóre publiczniejsze..., Poznań 1750-1752; zob. SPTK, t. 2, s. 41-43.

${ }^{86}$ Charakter nowy dawniejszej próby pióra addytamentami niektórych kazań..., Poznań 1744; zob. K. Estreicher, Bibliografia polska, t. 26, s. 318-320. 
tora Akademii Lubrańskiego i profesora Akademii Krakowskiej Stanisława Mamczyńskego (ok. 1750-1761) ${ }^{87}$, bernardyna, kaznodzieję katedry wawelskiej Antoniego Lipiewicza (XVIII w. $)^{88}$ oraz franciszkańskiego teologa ascetycznego i kaznodzieję Fortunata Łosiewskiego $(\dagger 1751)^{89}$. Lokalny akcent stanowił zbiór opata jędrzejowskiego a następnie biskupa inflanckiego i kamienieckiego Augustyna Adama Wessela (1678-1738 $)^{90}$. Dokładnie nie wiadomo, którymi zbiorami kazań reprezentowani byli jezuici, popularyzator teologii Franciszek Koczorowski (1687-1743) ${ }^{91}$, Stanisław Grodzicki (1541-1613) ${ }^{92}$ i Jan Krosnowski $(\dagger 1694)^{93}$. Na koniec omawiania polskich pomocy homiletycznych warto wymienić komentarz do kazań bpa Ratyzbony Alberta Wielkiego autorstwa historyka i heraldyka Szymona Okolskiego (1580-1653) ${ }^{94}$.

Zdecydowanie rzadziej w kościołach na terenie dekanatu Książ Wielki spotykane były pisma zagranicznych kaznodziejów. Najwięcej było ich w samym Książu Wielkim. Znajdowały się tam (w liczbie trzech egzemplarzy) kazania niemieckiego kaznodziei i egzegety Jana Wilda zwanego Ferusem (1494-1554) ${ }^{95}$, nadto homilie profesora filozofii i teologii w Tybindze Gabriela Biela $(\dagger 1494)^{96}$, bliżej niezidentyfikowane Sermones dominicales słynnego francuskiego kaznodziei, kanonika w Chartres i doktora Sorbony Jodoka Clichtoveusa $(\dagger 1543)^{97}$, Sermones jezuity, współtowarzysza Ignacego Loyoli - Alfonsa Salmeronisa (1514-1585) $)^{98}$, Homiliae niemieckiego kaznodziei i teologa kontrowersyjnego, profesora w Ingolstadt Jana Ecka (1486-1543) ${ }^{99}$, Homiliae belgijskiego minoryty Jana Royardusa $(\dagger 1547)^{100}$ oraz Apparatus Concionator hiszpańskiego jezuity Franciszka Labata $(\dagger 1613)^{101}$. Listę obcych autorów kazań zamykają proboszcz

\footnotetext{
${ }^{87}$ Chwała Bogu w niektórych mowach kaznodziejskich sercem i ustami niedawno... ogłoszona..., Poznań 1738; zob. SPTK, t. 3, s. 49-50.

${ }^{88}$ Kazania postne, Kraków 1745; zob. Estreicher, Bibliografia polska, t. 21, s. 301; PEK, t. $23-24$, s. 350 .

${ }^{89}$ Rozmyst na zmyst to jest kazania o pięciu zmysłach ludzkich..., Kraków 1735; zob. SPTK, t. 2, s. 576 .

${ }^{90}$ Droga do pobożności albo wprawa do takowego Ewangelii rozważania..., Warszawa 1728; zob. SPTK, t. 4, s. 408-409.

${ }^{91}$ SPTK, t. 2, s. 316-317.

${ }^{92}$ Tamże, t. 1, s. 592-594.

${ }^{93}$ Pelczar, Zarys dziejów, t. 2, s. 219.

${ }^{94}$ Praeco Verbi Divini, Kraków 1649; zob. Estreicher, Bibliografia polska, t. 23, s. 312.

${ }^{95}$ Postilla, Moguncja 1552-1555; zob. PEK, t. 41-42, s. 292; Hurter, Nomenclator, t. 1, s. 94 , t. 2, szp. 1486-1488.

${ }^{96}$ Sermones de tempore, Tybinga 1500; zob. Hurter, Nomenclator, t. 4, szp. 819; PEK, t. 3-4, s. 373 .

${ }^{97}$ EK, t. 3, s. 416.

${ }^{98}$ PEK, t. 35-36, s. 33.

${ }^{99}$ Homiliae, I-III Ingolstadt 1530-1531, IV Augsburg 1534, V Ingolstadt 1539; zob. LTK, b. 3 , kol, 441-442.

${ }^{100}$ Hurter, Nomenclator, t. 4, szp. 1345.

${ }^{101}$ Apparatus Concionator, wyd. 1621; zob. J. Pelczar, Zarys dziejów, t. 3, s. 422.
} 
w Ingolstadt, jezuita Mathias Faber (1587-1653) ${ }^{102}$, jezuita Jan Maior (1542-1608) ze Speculum exemplorum ${ }^{103}$, niemiecki kartuz, kaznodzieja i pisarz ascetyczny Joannes Justus Lanspergus (1490-1539) ${ }^{104}$ oraz nieznany bliżej Tomasz de Truxillo ${ }^{105}$.

Pośród kleru parafialnego rozpowszechnione były katechizmy i dzieła z zakresu teologii pastoralnej ${ }^{106}$, a więc wszystkie pozycje, które wspierały duchownych w codziennej pracy duszpasterskiej. Katechizmy rzymskie odnotowano w Sławicach, Książu Małym i Mstyczowie. Biblioteka parafialna w Radziemicach posiadała popularne dzieła norbertanina, kanonika pułtuskiego Jana Stanisława Kostki Wujkowskiego (XVIII w. $)^{107}$ oraz jezuity Marcina Hińczy $(1592-168)^{108}$. Najwięcej dzieł pastoralnych znajdowało się w księgozbiorze w Książu Wielkim. Były tam: katechizmy niemieckiego jezuity bł. Piotra Canisciusa (Kanicjusza) ${ }^{109}$ oraz Fryderyka Nausea (Blanci Campiani 1480-1552) bpa wiedeńskiego ${ }^{110}$, popularne dzieło wybitnego kanonisty Wilhelma Durandusa $(\uparrow 1295)^{111}$, a także Summa summarum dominikanina Sylvestra Prieriasa $(1456-1523)^{112}$. Pleban z Kaliny posiłkował się zaś pracą bernardyna Mercatora ${ }^{113}$ i Manuale Parochorum Karola Boromeusza. Duże znaczenie dla duszpasterstwa parafialnego miały w końcu listy pasterskie biskupów krakowskich. W Słaboszowie przechowywano listy bpa Felicjana Konstantego Szaniawskiego z 1720 r. i bpa Jana Aleksandra Lipskiego z 1737 r. W Książu Wielkim znajdujemy natomiast Refermationes Generales ad Clerum et Populum bpa Marcina Szyszkowskiego z $1621 \mathrm{r}$.

Przydatne $w$ pracy duszpasterskiej były traktaty $\mathrm{z}$ teologii moralnej ${ }^{114}$. Najstarszym dziełem z tego zakresu w omawianym dekanacie była Suma św. Tomasza z Akwinu przechowywana w Książu Wielkim i Łętkowicach. Niezwykle rozpowszechnione w Europie, bo mające ponad dwieście wydań, dzieło niemie-

${ }^{102}$ Conciones novae, Antwerpia 1647; zob. PEK, t. 11-12, s. 178-179.

${ }^{103}$ Estreicher, Bibliografia polska, t. 22, s. 247. Dzieło to zostało przetłumaczone na język polski przez Samuela Wysockiego i wydane w Krakowie w 1612 r.

${ }^{104}$ Sermones, Köln 1554-1556; zob. LTK, b. 6, kol 383. Dzieło to znajdowało się w zakrystii łętkowickiej świątyni jeszcze w XX wieku. Był to gruby tom, dobrze zachowany w tłoczonej oprawie z napisem „Joannis Justi Lanspergi Bavari carthusiani omnium Epistolarum et Evangeliorum dominicalium to. anni enarrationes etc. Wyd. kolońskie MDXLII, zob. Wiśniewski, Dekanat, s. 110 .

${ }^{105}$ Pelczar, t. 3, s. 267.

${ }^{106}$ Więcej na temat teologii pastoralnej zob. M. Jabłoński, Teoria duszpasterstwa (wiek XVIXVIII), DTK, t. 2, cz. 1

${ }^{107}$ Chleb duchowny... albo katechizm, Kalisz 1733; zob. SPTK, t. 4, s. 478-479.

${ }^{108}$ Gtos Pański z Ewangelii Adwentowych z naukami..., Wilno 1643; zob. SPTK, t. 2, s. 50-51; Estreicher, Bibliografia polska, t. 18, s. 200.

${ }^{109}$ LTK, b. 2, kol. 923.

${ }^{110}$ PEK, t, 27-28, s. 334-335.

${ }^{111}$ Rationale Divinorum officiorum, Moguntiae 1453; zob. PEK, t. 9-10, s. 198.

112 PEK, t. 31-32, s. 421

${ }^{113}$ Nucleus Catechisticus, Coloniae 1692; zob. K. Estreicher, Bibliografia polska, t. 22, s. 295.

114 Więcej na ten temat zob. J. Bajda, Teologia moralna (kazuistyczna) w XVII-XVIII wieku, DTK, t. 2, cz. 1 
ckiego teologa kazuisty Henryka Busenbauma (1600-1627) pt. Medulla thologiae moralis $^{115}$ znajdowało się tylko w Radziemicach, zaś jego rozszerzona przez niemieckiego jezuitę Claudiusza Lacroix (1652-1714) wersja w Sławicach ${ }^{116}$. Pozostali autorzy traktatów moralnych, których dzieła figurują w spisach książek parafialnych dekanatu Książ Wielki to: kanonik z Antwerpii Wawrzyniec Bayerlnick (1578-1627) ${ }^{117}$, doktor Sorbony, proboszcz w Paryżu, a następnie bp Rodez Ludwik Abelly (1604-1691) ${ }^{118}$. Z polskich moralistów wskazać trzeba dominikanina Mikołaja z Mościsk (1559-1632) ${ }^{119}$, krakowskiego dominikanina i moralisty Ferdynanda Januszowskiego Ohma (1639-1712) $)^{120}$, jezuite profesora Akademii Wileńskiej Jakuba Bartołda $(1670-1753)^{121}$, a zwłaszcza Szymona Makowskiego ${ }^{122}$.

Do działu teologii moralnej lub ascetycznej zaliczyć też należy podręczniki dobrego umierania ${ }^{123}$ autorstwa nieznanego bliżej Jana Baptisty de Vilela ${ }^{124}$, wielkopolskiego reformata Klemensa Bolesławiusza (ok. 1625-1689) ${ }^{125}$ a także niezidentyfikowane Modus iurandi moribundus i Trojakie na dobra śmierć przygotowanie.

Rozwijaniu życia wewnętrznego duchowieństwa służyły dzieła ascetyczne wszelkiego rodzaju rozmyślania i rozważania ${ }^{126}$. $\mathrm{Z}$ prac reprezentujących ascetykę na pierwszym miejscu wymienić należy utwór o charakterze modlitewnika z rekolekcjami, sposobem słuchania mszy św., z medytacjami i przygotowaniem do dobrej śmierci Viator Christianus in patriam tendens per moctus anagogicus opata cysterskiego w Koprzywnicy Antoniego Krzesimowskiego $(† 1706)^{127}$. Inni teologowie ascetyczni, po których dzieła sięgano w farach dekanatu Książ Wielki to: penitencjarz katedry włocławskiej Michał Rychalski (1654-1688) ${ }^{128}$, uznawany za ojca polskiej teologii ascetycznej reformata Chryzostom Dobrosielski (ok. 1605-1676) ${ }^{129}$, dominikanin Paweł Ruszel (1593-1658) ${ }^{130}$, Adam Augustyn Wessel

${ }^{115}$ Medulla theologiae moralis, Monastyr 1650; zob. PEK, t. 5-6, s. 231.

${ }_{116}$ Medulla theologiae moralis, Rawenna 1761; zob. EK, t. 11, s. 567.

${ }^{117}$ Promptuarium morale super Evangelia totius anni, Coloniae 1625; zob. PEK, t. 3-4, s. 293.

${ }^{118}$ Medulla theologica, Cracoviae 1709; zob. PEK, t. 1-2, s. 9.

${ }^{119}$ Theologia moralis ..., Cracoviae 1683; zob. SPTK, t. 3, s. 118-120.

${ }^{120}$ Sententiae thomisticae ..., Kraków 1696; zob. SPTK, t. 2, s. 169.

${ }^{121}$ Corona decenni explanationes theol. Moralis, Varsoviae 1726; zob. SPTK, t. 1, s. 115-116.

${ }^{122}$ Explanatio Decalogi, Kraków 1682; zob. W. Wicher, Szymon Makowski, s. 189-190.

${ }^{123}$ Szerzej o tej kategorii druków zob. G. Huszał, Przygotowanie do dobrej śmierci w XVII w., „Roczniki Humanistyczne”, 31 (1983) z. 2, s. 105-149.

${ }^{124}$ Praxis iurandi aegros ad Bene Moriendum, Cracoviae 1664; zob. Estreicher, Bibliografia polska, t. 33, s. 10.

${ }^{125}$ Homo bene moriens ..., Olivae 1685; zob. SPTK, t. 1, s. 189-190.

${ }^{126}$ Szerzej zob. K. Górski, Teologia ascetyczno-mistyczna (wiek XVI-XVIII), DTK t. 2, cz. 1.

${ }^{127}$ Viator Christianus in patriam tendens per moctus anagogicus, Kraków 1684; zob. SPTK, t. 1, s. 436-437; PEK, t. 23-24, s. 77.

${ }^{128}$ Quadriga sacerdotum ad coelum ..., Olivae 1686; zob. SPTK, t. 3, s. 354.

${ }^{129}$ Summarium asceticae et mysticae theologiae, Cracoviae 1655; zob. SPTK, t. 1, s. 402-404; Górski, Teologia ascetyczno-mistyczna, s. 444-448.

${ }^{130}$ Skarb nigdy nie przebrany, Lublin 1655; zob. SPTK, t. 3, s. 254. Praca ta zawiera wiele cen- 


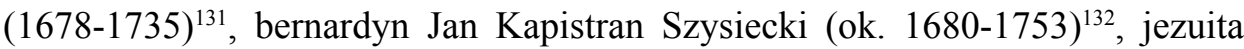
Adrian Miaskowski (1657-1737) ${ }^{133}$, niemiecki jezuita, spowiednik cesarzowej Amalii Maksymilian Dufrene $(\dagger 1765)^{134}$, lekarz, polemista i pisarz ascetyczny Kasper Wilkowski (VXVI w.) ${ }^{135}$, Vincenty Bruno z Rimini ${ }^{136}$, norbertanin, kanonik pułtuski Jan Stanisław Kostka Wujkowski ${ }^{137}$, włoski kardynał Robert Bellarmin (1542-1621) ${ }^{138}$, jezuita, profesor Akademii Wileńskiej Jerzy Tyszkiewicz (ok. $1571-1625)^{139}$.

W XVIII stuleciu czasy wielkich sporów teologicznych minęły, w związku $\mathrm{z}$ tym coraz rzadziej w librariach parafialnych rejestrowano dzieła $\mathrm{z}$ zakresu teologii polemiczno-dogmatycznej ${ }^{140}$. W kwestie dogmatyki i polemiki religijnej plebanów w dekanacie Książ Wielki wprowadzały dzieła: jezuity Adriana Miaskowskiego ${ }^{141}$, jezuity, spowiednika cesarza Ferdynanda II Martina Becanusa (1563-1624) $)^{142}$, bpa chełmskiego i warmińskiego, kardynała Stanisława Hozjusza $(1504-1579)^{143}$, jezuity i kanonisty Ignacego Głowackiego $(1667-1729)^{144}$, proboszcza jednej z parafii na Spiszu Kazimierza Kantego Młynarskiego (XVII/ XVIII w. $)^{145}$, wybitnego polskiego polemisty Marcina Śmigleckiego (15641619) ${ }^{146}$, Jakuba Wujka ${ }^{147}$, a w szczególności Adama z Opatowa ${ }^{148}$. Na koniec wspomnieć można nieokreślone Controversiae Alfonsa Mendosy i wreszcie zupełnie nieznane Asertionis Lutheranae Confutativ.

nych informacji na temat kultu Krzyża Św.

${ }^{131}$ Myśli pokutujqcego czlowieka ..., Kraków 1724; zob. SPTK, t. 4, s. 408-409.

${ }^{132}$ Firma quisensum ..., Poznań 1747; zob. SPTK, t. 4, s. 295-296.

${ }^{133}$ Expeditia salutis via per exercitia spiritualia; zob. SPTK, t. 3, s. 101.

${ }^{134}$ Sacerdio aut sanctus aut verprobus, Augasburg 1734; zob. PEK, t. 9-10, s. 177-178.

${ }^{135}$ Desiderosus albo ścieżka do miłości Bożej, Kraków 1589; zob. SPTK, t. 4, s. 435-436.

${ }_{136}$ Skarbnica tajemnic boskich albo rozmyślania żywota i męki Pana i Boga naszego, Kraków 1693; zob. Estreicher, Bibliografia polska, t. 13, s. 377.

${ }^{137}$ Medytacje, Warszawa 1742; zob. SPTK, t. 4, s. 278-279.

${ }^{138}$ De aeterna felicitate, Rzym 1616; zob. PEK, t. 3-4, s. 194-196.

${ }^{139}$ De perfectione Christiana, Cracoviae 1624; zob. SPTK, t. 4, s. 363-364.

${ }^{140}$ Szerzej o tej dyscyplinie teologii zob. M. Rechowicz, Teologia pozytywno-kontrowersyjna. Szkoła polska w XVI wieku, w: DTK, t. 2, cz. 1; B. Natoński, Humanizm jezuicki i teologia pozytywno-kontrowersyjna w XVII-XVIII wieku. Nauczanie i piśmiennictwo, w: DTK, t. 2, cz. 1.

${ }^{141}$ Deus in esentia unus in Personis trinus, Pragae 1723; Deus Homo seu Incarnatio Verbi divini, Pragae 1728; zob. SPTK, t. 3, s. 101.

${ }^{142}$ Compendium manualis contoversiarum, Mainz 1623; zob. EK, t. 2, s. 92.

${ }^{143}$ Confesio fidei catholicae christiana, Kraków 1553; zob. SPTK, t. 2, s. 68-75.

${ }^{144}$ Gladius Evaginatus, Kalisz 1725; zob. SPTK, t. 1, s. 53.

${ }^{145}$ Sermones familiares, Cracoviae 1701; zob. SPTK, t. 3, s. 148-149; Estreicher, Bibliografia polska, t. 22, s. 460.

${ }^{146}$ O bóstwie przedwiecznym syna Bożego, Wilno 1595, zob. NK, t. 3, s. 325-327.

${ }_{147}$ O Bóstwie Syna Bożego i Ducha Świętego przeciw Żydom, Mahometanom, Arianom,..., Kraków 1590; zob. K. Estreicher, Bibliografia polska, t. 33, s. 381.

${ }^{148}$ Tractatus de sacramentis in genere et specia, Cracoviae 1642; zob. F. Bracha, Adam Opatowski (1574-1647). W 300-letniq rocznicę śmierci, „Nasza Przeszłość”, t. 3, 1947, s. 132. 
Niezwykle rzadko w staropolskich księgozbiorach tak parafialnych jak i prywatnych występowała Biblia ${ }^{149}$. Na terenie dekanatu ksiąskiego odnotowano Pismo Św. tylko w czterech kościołach (z czego w Radziemicach w dwóch egzemplarzach). Nieco częściej w bibliotekach farnych pojawiały się komentarze do Pisma Św. ${ }^{150}$ Największy zbiór tego typu literatury posiadał kościół w Książu Wielkim. Były tam Interpretationes kartuza Dionizego de Ryckel (1402-1471) ${ }^{151}$, komentarze hiszpańskiego jezuity Antoniego Velasqueza $(† 1669)^{152}$, nieokreślone bliżej Enarrationes niemieckiego kartuza Jana Justusa Lanspergusa (1490$1539)^{153}$, komentarze hiszpańskiego jezuity, profesora w Combrze i Evorze Blasiusa Viegasa $(† 1599)^{154}$, nieznane komentarze Haymona $(\dagger 853)$ benedyktyna zFuldy, bpaHalberstadt, uczniaAlkuina ${ }^{155}$,atakżeConcordantiaeBibliorumiLexicon Biblicum, o których to jednak nic bliższego powiedzieć nie można. W innych bibliotekach natrafiano na komentarze franciszkanina z Nawary Dydaka Stelli ${ }^{156} \mathrm{i}$ belgijskiego minoryty Antoniusa Broickwy de Koenigsten $(\dagger 1541)^{157}$. W tym miejscu wymienić jeszcze warto dzieło Sepultura viventium bożogrobca Jakuba Radlińskiego (ok. 1680-1762) pełniące rolę komentarza do psałterza ${ }^{158}$.

Bardzo słabo w księgozbiorach parafialnych wczesnonowożytnej Polski reprezentowana była historia Kościoła. Ten dział w bibliotekach parafialnych dekanatu Książ Wielki reprezentują jedynie roczniki Cesara Baroniusza (1538-1607) włoskiego historyka Kościoła, kardynała i kaznodziei ${ }^{159}$ odnotowane w Książu Wielkim oraz dzieło poświęcone historii obrazu Matki Boskiej Częstochowskiej, paulina, mariologoa i historyka Ambrożego Nieszporkowica (1634-1703) ${ }^{160}$.

W skromnej liczbie reprezentowane są też żywoty świętych ${ }^{161}$. W Książu Małym przechowywano obszerny, bo liczący 900 stron zbiór żywotów greckich i egipskich ojców pustyni przetłumaczony na prośbę Katarzyny z Sobieskich Radziwiłłowej przez Sebastiana Piskorskiego ${ }^{162}$, a ponadto Żywot Michała

${ }^{149}$ Por. Kracik, Biblioteki parafialne, s. 261, Wyczawski, Biblioteki parafialne, s. 33, K. M. Kowalski, Księgozbiory parafialne, s. 31-32, 87-150, Główka, Księgozbiory duchowieństwa, s. 25.

${ }^{150}$ Szerzej na ten temat zob. W. Smereka, Biblistyka polska (wiek XVI-XVII) w: DTK, t. 2 , cz. 1 .

${ }^{151}$ PEK, t. 9-10, s. 226-228.

${ }^{152}$ Commentarium in Epistolam b. Pauli Ap. ad Philipenses; zob. H. Hurter, Nomenclator, t. 2, szp. 148.

${ }^{153}$ LTK, b. 6, kol. 383.

${ }^{154}$ Commentarium in Apocalipsum, Eborae 1601; zob. H. Hurter, Nomenclator, t. 1, s. 94.

${ }^{155}$ PEK, t. 15-16, s. 67.

${ }^{156}$ Komentarz na Ewangelie św. Lukasza, Salamanka 1581; zob. PEK, t. 37-38, s. 128.

${ }^{157}$ In quatuor Evangelia Enarrationes, Coloniae 1539; zob. Hurter, Nomenclator, t. 4, szp. 1281.

${ }^{158}$ SPTK, t. 3, s. 479-481.

${ }_{159}$ Annales Eclesiastici, Antwerpiae 1597; zob. Estreicher, Bibliografia polska, t. 1, s. 376;

PEK, t. 3-4, s. 122.

${ }^{160}$ Odrobiny stołu królewskiego ..., Kraków 1683; zob. SPTK, t. 3, s. 374.

161 Charakterystykę hagiografii polskiej $\mathrm{w}$ okresie przedrozbiorowym przedstawiła U. Borkowska, Hagiografia polska (wiek XVI-XVIII), DTK, t. 2, cz. 1.

${ }^{162}$ Żywoty Ojców ..., Kraków 1688; zob. SPTK, t. 3, s. 210-212. 
Giedroycia pióra lwowskiego kanonika, profesora Akademii krakowskiej Jana z Trzciany (ok. 1510-1730) ${ }^{163}$ oraz Vitae S. Vladislai Regni Hungariae. W Radziemicach zgromadzono natomiast hagiograficzny utwór Piotra Skargi ${ }^{164}$, a także Beatyfikacje Wielkiego Stugi Bożego Wincentego a Paulo ${ }^{165}$.

Jeśli chodzi o prawo kanoniczne ${ }^{166}$, to i tu panował niedostatek. W Książu Wielkim znajdował się słynny Corpus Iuris Canonici ${ }^{167}$ oraz Conciliorum Tridentinum. Ustawy synodalne to Synodus dioecesana Luceorrierusis celebrata (1607) Marcina Szyszkowskiego w Sławicach oraz Synodorum Diakonarum Liber. Nadmienić też należy, że radziemicka biblioteka posiadała także Index librorum prohibitorum $^{168}$. W Książu Małym z kolei przechowywano dzieło prawnicze pióra profesora Akademii Wileńskiej i Akademii Lubrańskiego, Stanisława Mamczyńskiego (ok. 1700-1761) ${ }^{169}$, stanowiące traktat o zadaniach komisarza dokonującego z ramienia oficjała czynności procesowych.

Pisma Ojców Kościoła: św. Bazylego Wielkiego i św. Cyryla ${ }^{170}$ napotkano jedynie w Książu Wielkim.

Spis literatury teologicznej zamykają dzieła poświęcone liturgii. Pierwsze autorstwa G. Rippela przetłumaczone na język polski przez reformata Protazego Neweraniego (1702-1743) stanowi opis zwyczajów liturgicznych ${ }^{171}$. Drugie z kolei to pismo pióra jezuity Tomasza Młodzianowskiego (1622-1686) ${ }^{172}$.

Bardzo skromnie przedstawia się literatura świecka w księgozbiorach parafialnych dekanatu Książ Wielki. Podzielona została ona na dwa działy: naukę i literaturę piękną.

Do pierwszej grupy zaliczyć trzeba słowniki i gramatyki. W Łętkowicach znajdował się Dictionarium lingue latinae oraz Ortographiae Commentariarorum Gramaticorum Joannis Tertilli Auretini, zaś w Książu Wielkim pod sformułowaniem Knapiusz rozumieć należy jeden ze słowników Grzegorza Knapskiego (1564-1639) jezuity, leksykografa i dramatopisarza ${ }^{173}$. Sztuki wymowy proboszcz

${ }^{163}$ Żywot blogostawionego Michała Gedrocia ..., Kraków 1615; zob. SPTK, t. 2, s. 149-150.

164 Żywoty Świętych, Wilno 1579; zob. NK, t. 3, s. 236-237.

${ }^{165}$ Beatyfikacja Wielkiego Stugi Bożego Wincentego a Paulo, Kraków 1615; zob. Estreicher, Bibliografia polska, t. 33, s. 42-43.

${ }^{166}$ Szerzej: A. Petrani, Historia prawa kanonicznego (wiek XVI-XVIII), DTK, t. 2, cz. 1, s. $512-$ $-513$.

${ }^{167}$ Corpus Iuris Canonici, Rzym 1582; zob. H. E. Wyczawski, Biblioteki parafialne, s. 62.

${ }^{168}$ W Polsce Indeks Ksiag Zakazanych wydrukowany został w 1603 i 1617 r. w Krakowie oraz w Zamościu w 1604 r. W Radziemicach mogło też znajdować się któreś z zagranicznych wydań indeksu, np. rzymskie z roku 1704 czy 1758; zob. K. Estreicher, Bibliografia polska, t. 8, s. 565-566 .

169 Praxis commisarialis fori spiritualis compendiossima, Posnaniae 1738; zob. SPTK, t. 3 , s. 49-50.

${ }^{170}$ Bazyli Wielki, Opera, Bazylea 1540; Św. Cyryl, Opera, Paryż 1572; zob. Rył, Biblioteka katedralna., t. 36, 1978, s. 215.

${ }^{171}$ Ozdoba kościoła katolickiego to jest ceremonie, których kościót [...] zwykł zażywać, Lwów 1739; zob. SPTK, t. 3, s. 200.

${ }^{172}$ Liturgia seu modus celebrandi, Warszawa 1754; zob. SPTK, t. 3, s. 143-146.

${ }^{173}$ NK, t. 2, s. 328-330. 
w Książu Małym uczył się czytając pracę jezuity Cypriana Soareza (1547-1617) Rhetoricae libri tres ${ }^{174}$. Z dziedziny filozofii wspomnieć trzeba przede wszystkim podręcznik tej dyscypliny, którego autorem był Szymon Makowski ${ }^{175}$. Być może pozycja określona $\mathrm{w}$ inwentarzu małoksiąskim jako Propheta, to filozoficzno-medyczne dzieło słynnego filozofa i przyrodnika Konrada Gesnera ${ }^{176}$. W bibliotece w Książu Wielkim odnotowane zostały też dwie pozycje z zakresu arytmetyki: pierwsza profesora Akademii Krakowskiej Jana Brożka (1585-1652) ${ }^{177}$, druga profesora Akademii Wileńskiej, jezuity Wojciecha Tylkowskiego (1625-1695) $)^{178}$. Historię powszechna Tytusa Liviusza zasygnalizowano w Nasiechowicach jako Annales Titii Livii ${ }^{179}$. W Książu Wielkim przechowywano jedyne w całym dekanacie dzieło geograficzne portugalskiego jezuity, profesora filozofii w Combrze i Evorze Sebastiana Barradasa (1542-1615) ${ }^{180}$.

Jeszcze rzadsze były pozycje z zakresu literatury pięknej. $Z$ autorów starożytnych w Książu Małym znajdowała się Opera łacińskiego pisarza i filozofa Luciusa Caeliusa Firmaniusa (ok. 250-ok. 330) ${ }^{181}$. Dzieło zasygnalizowane w Książu Wielkim jako Tabulae Terrentii, to zapewne jakieś komedie rzymskiego dramatopisarza Publiusa Terentiusa Afera (II w. p.n.e.) ${ }^{182}$. Z polskiej literatury pięknej czytano utwory jezuity i wierszopisa Piotra Kwiatkowskiego (1664-1747) ${ }^{183}$ oraz naśladowcy pisarzy antycznych Horacego i Owidiusza Jana Damascena Kalińskiego (1664-1726) poety i kaznodzieja pijarskiego ${ }^{184}$.

Cechą charakterystyczną zawartości parafialnych księgozbiorów dekanatu Książ Wielki jest duża rozmaitość pojedynczych egzemplarzy dzieł. Żadna pozycja nie uzyskała w świetle zgromadzonych materiałów znacznej przewagi nad innymi. Powyższa uwaga odnosi się też do autorów.

Analiza zasobów bibliotek parafialnych nie pozostawia wątpliwości, że przeważały (nieznacznie) pisma polskich autorów (ok. 55\%) nad obcymi (45\%). 57\% wykazanych autorów to zakonnicy. Spośród tej grupy 25\% stanowią jezuici, a 14\% księża różnych odłamów rodziny franciszkańskiej.

Czytano przede wszystkim po łacinie (64\% dzieł) i po polsku (32\%) $)^{185}$. Tylko w Książu Wielkim napotkano kilka książek w języku francuskim i włoskim.

${ }^{174}$ Rhetoricae libri tres; zob. Estreicher, Bibliografia polska, t. 28, s. 341.

${ }^{175}$ Cursus philosophicus, Cracoviae 1679-1681; zob. W. Wicher, Szymon Makowski, s. 127.

${ }^{176}$ K. M. Kowalski, Księgozbiory, s. 131, przyp. 3.

177 Arithmetica integrorum, Cracoviae 1620; zob. SPTK, t. 1, s. 251-220.

${ }^{178}$ Arithmetica curiosa, Cracoviae 1668; zob. SPTK, t. 4, s. 358-362.

${ }^{179}$ Fasti Romanorum Liviani hoc est annorum, Gdańsk 1676; zob. Estreicher, Bibliografia polska, t. 21, s. 556-557.

${ }^{180}$ Itinearium filiorum ex Israel ex egypto, Antwerpiae 1612; zob. Hurter, Nomenclator, t. 1, s. 187-188; PEK, t. 3-4, s. 122.

${ }^{181}$ SPA, s. 282-283.

182 Tamże, s. 446-448.

${ }^{183}$ Teatr życia ludzkiego, Kraków 1736; zob. NK, t. 1, s. 436-437.

${ }^{184}$ Zodiacus Caeli Sarmatici, Varsoviae 1715; zob. Estreicher, Bibliografia polska, t. 19, s. 59.

${ }^{185}$ Należy zaznaczyć, że statystykę tę, podobnie jak poprzednią zawyża księgozbiór w Książu Wielkim, gdzie obcy twórcy i ich łacińskie dzieła odniosły druzgocącą przewagę nad polskimi autorami i polskim językiem. 
Przeważały wydania polskie (główne ośrodki wydawnicze to: Kraków, Poznań, Warszawa, Kalisz, Częstochowa, Lublin, Wilno i Sandomierz) ale były także egzemplarze zagraniczne, wydane w Kolonii, Antwerpii, Moguncji, Ingolstadt, Monastyrze, Rawennie, Tybindze i Bazylei.

Udało się ustalić daty wydań 140 tytułów książek, co ilustruje wykres nr 1 . Oczywiście wskazano jedynie daty pierwszych wydań gdyż źródło nie pozwala na dokładne ustalenia w tym względzie. $19 \%$ tytułów wydanych zostało jeszcze w XVI w. lub wcześniej, 50\% w XVII w. Jedynie 31\% dzieł to druki osiemnastowieczne. Porównując, dzięki przedstawionemu poniżej wykresowi, daty pierwszych edycji książek z datą wizytacji dekanatu Książ Wieki zauważyć trzeba, że dzieli je kilkadziesiąt a nawet kilkaset lat. Brak świeżych tytułów w parafialnych księgozbiorach świadczy o ich drugorzędnej roli w życiu intelektualnym duchowieństwa. Stanowiły one jedynie ,rodzaj jakiegoś instytucjonalnego antykwariatu, gdzie składowano używane książki i skąd je zabierano" ${ }^{186}$. Znaczenie podstawowe zapewne musiały mieć, nie zarejestrowane w 1783 r. biblioteki osobiste. Jak jednak było w rzeczywistości nie wiadomo, dlatego też w tym zakresie nie można wyjść poza domysły.

W okresie przedrozbiorowym księgozbiory parafialne powstawały i narastały przede wszystkim drogą darowizn i zapisów testamentalnych dokonywanych przez duchownych na rzecz swoich parafii, rzadziej zaś dzięki planowym i systematycznym zakupom ${ }^{187}$. Natomiast sytuacje takie jak w Żółkwi, gdy biblioteka farna zasilana była dzięki książkom z rąk świeckich donatorów ${ }^{188}$, były zapewne sporadyczne. Akta wizytacji dekanatu Książ Wielki na temat genezy księgozbiorów przeważnie milczą, poza jednym przypadkiem, mianowicie wizytator wspomina, że książki w kościele w Radziemicach pochodzą z daru plebana tegoż kościoła księdza Jana Jarzeńskiego (Jarzyńskiego) ${ }^{189}$. Skądinąd wiadomo, że bibliotekę w Książu Wielkim zaopatrzył dzięki swemu zapisowi ks. Adam Brachman, proboszcz w latach 1763-1782 $2^{190}$.

Niezwykle interesującym, ale wobec milczenia w tej sprawie źródeł trudnym do rozwiązania problemem jest miejsce i sposób przechowywania parafialnych księgozbiorów. Przeważnie książki umieszczano w zakrystiach, w szafach lub skrzyniach, rzadziej w skarbcach ${ }^{191}$. Pozycje nieużywane składowano w rozmai-

${ }^{186}$ Kracik, Biblioteki parafialne, s. 270.

${ }^{187}$ Kracik, Biblioteki parafialne, s. 253-254; W. Olszewicz, Z dziejów bibliotek i miłośnictwa ksiażki w Polsce w XVIII w., RB, 12 (1968) s. 58-60.

${ }^{188}$ J. Mayer, O ksiqżkach z daru Reginy Żółkiewskiej, Jana Żółkiewskiego i Teofili Sobieskiej dla kościoła parafialnego w Żółkwi, PB, 7 (1933) z. 4, s. 163-171.

${ }^{189}$ AKMKr, AV 54, s. 239: „Książki te ofiarowane są kościołowi przez Ś.P. JM księdza Jana Jarzyńskiego plebana niegdysiejszego tego kościoła z obowiązkiem owych następców aby pilnie były przechowywane, którego pobożna myśl aby swój skutek mocą niniejszej wizyty wszystkich następnych obowiązujemy [...] aby ten kosztowny skarb szanowali i bez uszkodzenia zachowali na zawsze". Jan Jarzeński był plebanem kościoła radziemickego w latach 1736-1740, zob. Wiśniewski, Dekanat, s. 200.

${ }^{190}$ Wiśniewski, Dekanat, s. 83.

${ }^{191}$ Por. Kowalski, Księgozbiory parafialne, s. 25-28; J. Szymański, Archiwum i biblioteka pa- 
tych składzikach i stryszkach ${ }^{192}$. Protokoły wizytacji Poniatowskiego nie przekazują na ogół jak wyglądało przechowywanie bibliotek w kościołach parafialnych na terenie dekanatu ksiąskiego. Wiadomo jedynie, że zarówno w Książu Wielkim jak i w Łętkowicach książki umieszczono w zakrystii w specjalnych szafach ${ }^{193}$. Podobnie zapewne było w innych świątyniach. Jedynie w Miechowie bogaty księgozbiór klasztorny umieszczono w osobnym pomieszczeniu nad kruchtą ${ }^{194}$.

Nie wszędzie jednak należycie dbano o książki, a najmniej bodaj w Nasiechowicach, gdzie tamtejszy księgozbiór w znacznej części uległ zniszczeniu zgnił195. I w innych parafiach stan książek nie był zadowalający, często ich oprawy były zepsute, karty podarte, a niektóre księgi doczekały wizytacji zaledwie w kawałkach ${ }^{196}$. Nie dziwi więc fakt, że notariusz wizytacyjny nierzadko zamieszczał notkę o konieczności reparacji uszkodzonych pozycji ${ }^{197}$.

Zdumiewa fakt, że o ile w ustawodawstwie kościelnym dosyć często podnoszono temat bibliotek parafialnych, nakazując ich zaopatrywanie w najnowsze publikacje teologiczne, a niekiedy nawet zestawiając spisy ,obowiązkowych lektur" dla parafialnego kleru, o tyle egzekwowanie tych postanowień pozostawiało wiele do życzenia ${ }^{198}$. Niezwykle bowiem rzadko zdarzało się, aby w zaleceniach powizytacyjnych zwróconą uwagę na brak czy szczupłość biblioteki, nie mówiąc o nakazie zakupu nowych książek ${ }^{199}$.

Reasumując wizytacja Poniatowskiego z 1783 r. we wszystkich parafiach dekanatu ksiąskiego zastała księgi liturgiczne. Biblioteki stwierdzono w 11 z 16 parafii. Analiza zawartości bibliotek parafialnych dekanatu Książ Wielki oparta na identyfikacji i klasyfikacji gatunkowej książek nie pozostawia żadnych wątpliwości, że zgromadzono w nich w zasadzie jedynie literaturę teologiczną. Przewaga pomocy homiletycznych, dzieł pastoralnych, ascetycznych i poświęconych teologii moralnej świadczy o ich wybitnie użytkowym charakterze. Wszystkie te pozycje wspierać miały duchownych zarówno w konfesjonale jak i na ambonie. Kler parafialny mniejsze znaczenie natomiast przywiązywał do przeżywającej swój zmierzch dogmatyki i polemiki religijnej, a niemal zupełnie nie interesował się

rafialna w Wojniczu, ABMK, 2 (1962) z. 1-2, s. 174; Moskal, Biblioteki parafialne, s. 86-79.

${ }^{192}$ Kracik, Biblioteki parafialne, s. 268; Kowalski, Ksiegozbiory parafialne, s. 25-28.

${ }^{193}$ AKMKr, AV 54 s. 246: w kościele w Łętkowicach ,[...] dwie ściany tej zakrystii [...] zabudowane szafami z których w jednej biblioteka kościelna"; zaś w Książu Wielkim, AKMKr, AV 54, s. 308: „w zakrystii dwie szafy w jednej z nich biblioteka kościelna”.

${ }^{194}$ Katalog zabytków sztuki w Polsce, t. 1: Województwo krakowskie, z. 8: Powiat miechowski, Warszawa 1953, s. 21.

${ }^{195}$ AKMKr AV 54, s. 256: ,[...] prócz wyrażonych były jeszcze i inne [księgi] [...] lecz przez złą konserwację pogniły".

${ }^{196}$ Przykładowo w Sławicach, AKMKr, AV 54, s. 268: „wszystkie te książki w złej oprawie, podarte”; zaś w Kozłowie,AKMKr,AV 54, s. 249:,„[mszału] trzeciego kawałek tylko”; a w Radziemicach, AKMKr, AV 54, s. 239: „Żywoty S.S. Pańskich niecałe”.

${ }^{197}$ Na przykład w Radziemicach, AKMKr, AV 54, s. 238: „Graduał i antyfonarz reparacji potrzebuje".

${ }^{198}$ Moskal, Biblioteki parafialne, s. 53-66.

${ }^{199}$ Jedynie w dekretach powizytacyjnych dla parafii Racławice znaleźć można wzmiankę o konieczności zakupu nowych ksiąg, AKMKr, AV 54, s. 376. 
historią Kościoła i prawem kanonicznym. Rzadko występowała również Biblia. Niezwykle skromna literatura pozareligijna służyła jako uzupełnienie dzieł teologicznych (np. słowniki i gramatyki, pisma autorów starożytnych). Przeważały dzieła autorów polskich. Czytano w zasadzie jedynie po łacinie i po polsku. Większość pozycji została wydana w Polsce. Analiza dat pierwszych wydań poszczególnych tytułów książek zgromadzonych w bibliotekach parafialnych dekanatu Książ Wielki wykazała, że połowę wszystkich dzieł stanowiły druki siedemnastowieczne, jedną trzecią zaś szesnastowieczne. Pozycje wydane w wieku XVIII to zaledwie $18 \%$ wszystkich tytułów. Brak świeżych tytułów w tychże zbiorach świadczy o tym, że książnice te stanowiły rodzaj magazynów czy antykwariatów. Przypuszczać jedynie można, że podstawowe znaczenie dla kształtowania kultury intelektualnej duchowieństwa miały pominięte przez wizytację biblioteki osobiste, zwłaszcza w tych parafiach, w których brak było księgozbioru instytucjonalnego lub jego objętość była skromna. Powyższe uwagi o ewentualnych bibliotekach prywatnych wobec braku odpowiednich przekazów źródłowych pozostaja jedynie $\mathrm{w}$ sferze hipotez.

Tabela 1. Księgi liturgiczne w parafiach dekanatu Książ Wielki w 1783 r.

\begin{tabular}{|c|c|c|c|c|c|c|c|c|c|c|c|}
\hline Parafia & $\sum_{\Sigma}^{\bar{N}}$ & 苞 & 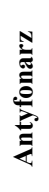 & 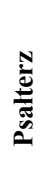 & 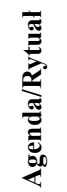 & 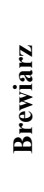 & 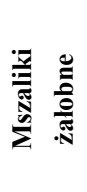 & 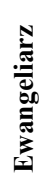 & 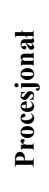 & 菊 & שี \\
\hline Radziemice & 3 & 1 & 1 & 1 & $1 / 1 \mathrm{R}$ & 3 & 3 & 2 & - & 2 & 18 \\
\hline Łętkowice & 4 & - & 1 & 1 & $1 / 1 \mathrm{R}$ & - & 3 & 1 & 1 & 2 & 15 \\
\hline Nasiechowice & 5 & 1 & 1 & 1 & 1 & - & 2 & 1 & 1 & 2 & 15 \\
\hline Sławice & 1 & - & - & 1 & $1 \mathrm{R}$ & - & 1 & 1 & - & 1 & 6 \\
\hline Mstyczów & 4 & 1 & - & - & $2 \mathrm{R}$ & - & 2 & 1 & - & - & 10 \\
\hline Kozłów & 3 & - & 1 & & 1 & - & 2 & 1 & - & 2 & 10 \\
\hline Książ Wielki & 6 & 1 & 1 & $1^{\mathrm{a}}$ & 1 & - & 6 & 1 & - & 2 & 19 \\
\hline Miechów & 14 & - & - & - & - & - & 5 & - & - & - & 19 \\
\hline Kalina & 6 & 1 & 1 & 1 & $1 \mathrm{R}$ & - & 3 & 1 & 1 & 2 & 17 \\
\hline Racławice & 2 & - & 1 & - & 1 & - & 2 & 1 & - & 1 & 8 \\
\hline Zielenice & 4 & 1 & 1 & 1 & 3 & - & - & - & 1 & - & 11 \\
\hline Wrocimowice & 4 & 1 & 1 & - & 1 & 2 & 2 & 1 & 1 & 2 & 15 \\
\hline Pałecznica & 3 & 1 & 1 & 1 & 1 & - & 2 & 1 & 1 & 1 & 12 \\
\hline Małoszów & 4 & - & - & - & - & - & 2 & - & - & 2 & 8 \\
\hline Słaboszów & 4 & 1 & 1 & 1 & 1 & 1 & 4 & 1 & - & 1 & 15 \\
\hline Książ Mały & 4 & 1 & 1 & 1 & 1 & $1^{\mathrm{b}}$ & 3 & 1 & - & 2 & 15 \\
\hline Razem & 71 & 10 & 12 & 10 & 19 & 7 & 42 & 14 & 6 & 22 & 213 \\
\hline w\% & 33 & 5 & 6 & 5 & 9 & 3 & 20 & 6 & 3 & 10 & 100 \\
\hline
\end{tabular}

${ }^{\mathrm{a}}$ nadto książka kursowa jedna ${ }^{\mathrm{b}}$ nadto diurnał

Uwaga: Litera R przy liczbie w rubryce agenda/rytuał oznacza ilość rytuałów.

Podstawa tabeli: AKMKr, AV 54, s. 238-239, 249, 256-257, 267-268, 279, 298, 314-315, 353, 365 , 372, 380, 402, 409, 417, 429-430. 
Tabela 2. Liczba książek w bibliotekach parafialnych dekanatu Książ Wielki w 1783 r.

\begin{tabular}{|l|c|c|}
\hline \multicolumn{1}{|c|}{ Parafia } & Księgi liturgiczne & Literatura pomocnicza \\
\hline Radziemice & 18 & $47^{\text {a }}$ \\
\hline Łętkowice & 15 & 19 \\
\hline Nasiechowice & 15 & 17 \\
\hline Sławice & 6 & 8 \\
\hline Mstyczów & 10 & 4 \\
\hline Kozłów & 10 & 98 \\
\hline Książ Wielki & 20 & $-{ }^{\mathrm{b}}$ \\
\hline Miechów & 19 & $10^{\mathrm{c}}$ \\
\hline Kalina & 17 & - \\
\hline Racławice & 8 & - \\
\hline Zielenice & 11 & - \\
\hline Wrocimowice & $15^{\mathrm{d}}$ & - \\
\hline Pałecznica & $12^{\mathrm{e}}$ & - \\
\hline Małoszów & 8 & 9 \\
\hline Słaboszów & 15 & 91 \\
\hline Książ Mały & 16 & 314 \\
\hline Razem & 215 & - \\
\hline
\end{tabular}

${ }^{a}$ ponadto książka św. Józefa [bracka] ${ }^{\mathrm{b}}$ brak dokładnych danych o liczbie książek ${ }^{\mathrm{c}}$ poza tym księga bracka ${ }^{\mathrm{d}}$ ponadto dwie księgi brackie i książeczka do chorych ${ }^{\mathrm{e}}$ nadto książka bracka.

Podstawa: AKMKr, AV 54, s. 238-239, 249, 256-257, 267-268, 279, 298, 314-315, 353, 365, 417, 429,430 .

Tabela3. TematykaksiążekwksięgozbiorachparafialnychwdekanacieKsiążWielkiw 1783 roku.

\begin{tabular}{|l|c|c|}
\hline \multicolumn{1}{|c|}{ Kategoria } & Liczba dziel & \% \\
\hline teologia & 257 & 81,9 \\
\hline nauka & 17 & 5,4 \\
\hline literatura piękna & 7 & 2,2 \\
\hline nieokreślona & 33 & 10,5 \\
\hline razem & 314 & 100 \\
\hline
\end{tabular}

Podstawa: AKMKr, AV 54, s. 238-239, 249, 256-257, 267-268, 279, 298, 314-315, 353, 365, 417, $429,430$.

Tabela 4. Literatura religijna w księgozbiorach parafialnych dekanatu Książ Wielki w 1783 roku.

\begin{tabular}{|l|c|c|}
\hline \multicolumn{1}{|c|}{ Rodzaj } & Liczba dziel & \% \\
\hline \multicolumn{1}{|c|}{$\mathbf{1}$} & $\mathbf{2}$ & $\mathbf{3}$ \\
\hline homiletyka & 98 & 38 \\
\hline teologia moralna & 27 & 8,5 \\
\hline teologia ascetyczna & 21 & 6 \\
\hline teologia pastoralna & 16 & 5,5 \\
\hline teologia polemiczno-dogmatyczna & 14 & 8 \\
\hline
\end{tabular}




\begin{tabular}{|l|c|c|}
\hline \multicolumn{1}{|c|}{$\mathbf{1}$} & $\mathbf{2}$ & $\mathbf{3}$ \\
\hline liturgika & 3 & 1 \\
\hline biblistyka & 16 & 6 \\
\hline prawo kanoniczne & 7 & 3 \\
\hline hagiografia & 7 & 3 \\
\hline historia Kościoła & 6 & 2,5 \\
\hline Ojcowie Kościoła & 3 & 1 \\
\hline Biblia & 9 & 3,5 \\
\hline nieokreślony & 30 & 12 \\
\hline razem & 257 & 100 \\
\hline
\end{tabular}

Podstawa: AKMKr, AV 54, s. 238-239, 249, 256-257, 267-268, 279, 298, 314-315, 353, 365, 417, $429,430$.

Wykres 1. Daty pierwszych wydań książek w bibliotekach parafialnych dekanatu Książ Wielki w 1783 r.

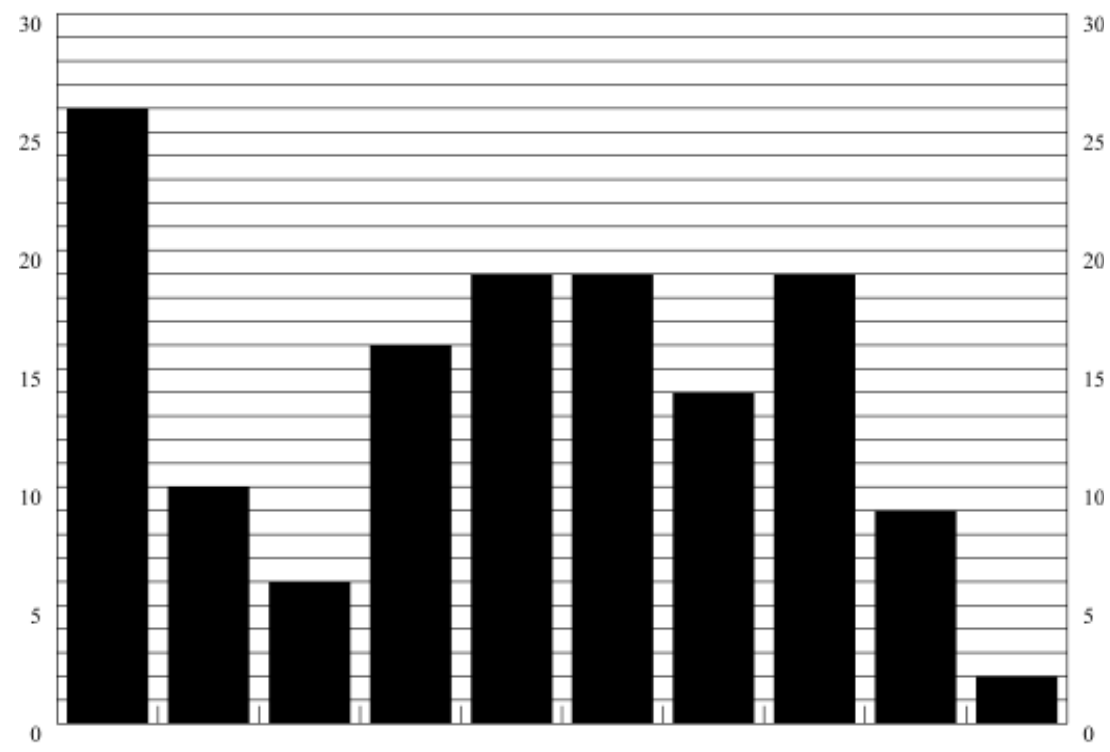

do 1600 1601-1620 1621-1640 1641-1660 1661-16801681-1700 1701-1720 1721-1740 1741-1760 1761-1780

Podstawa: K. Estreicher, Bibliografia polska XVI-XVIII wieku, cz. 3, t. 1-33, Kraków 1891-1939; H. Hurter, Nomenclator litterarius theologiae catholicae, t. I-IV, Oeniponti 1903-1913; Stownik Polskich Teologów Katolickich, red. H. E. Wyczawski, t. 1-4, Warszawa 1981-1983; Podręczna Encyklopedia Kościelna, t. 1-44, wyd. Z. Chełmnicki i in., Warszawa 1904-1916; Nowy Korbut. Bibliografia Literatury Polskiej. Piśmiennictwo Staropolskie, oprac. zespół pod kierunkiem R. Pollaka, t. 1-3, Warszawa 1963-1965; Lexicon für Theologie und Kirche, hrsg., von W. Kasper, b. 1-9, Freiburg-Basel 1993-2000; Encyklopedia kościelna podtug teologicznej encyklopedii Weltzera $i$ Weltego z licznymi jej dopetnieniami, przy wspótpracownictwie kilkunastu duchownych $i$ świeckich osób wydana przez ks. Nowodworskiego, t. 1-33, Warszawa-Włocławek 1873-1933; J. Pelczar, Zarys dziejów kaznodziejstwa, t. 1-3, Kraków 1896-1900; Stownik Pisarzy Antycznych, red. A. Świderkówna, Warszawa 1982. 


\title{
DIE PFARRBIBLIOTHEKEN IM DEKANAT KSIĄŻ WIELKI IN DER ZWEITEN HÄLFTE DES 18. JAHRHUNDERTS
}

\begin{abstract}
Zusammenfassung
Das Ziel des vorliegenden Artikels ist es, dem Leser die Bestände der Pfarrbibliotheken auf dem Territorium des Dekanats Książ Wielki, das damals Teil des zur Krakauer Diözese gehörenden Archidiakonats Kraków war, in der zweiten Hälfte des 18. Jahrhunderts näherzubringen. Als Quellengrundlage dieses Artikels fungieren die Inventarverzeichnisse der Pfarrbibliotheken, wie sie in den Akten der 1783 auf Anordnung von Erzbischof Michał Poniatowski durchgeführten Visitation des Dekanats Książ enthalten sind, welche gegenwärtig im Archiv der Metropolitankurie in Kraków aufbewahrt werden. Diese Quelle informiert zuerst über alle am Ende des 18. Jahrhunderts in den Pfarreien des Dekanats Książ Wielki vorhandenen liturgischen Bücher. Danach kopierte der Visitator die Bibliotheksverzeichnisse, die die gesamte Hilfsliteratur umfassten, welche die Geistlichen in ihrer Seelsorge- und Predigtarbeit unterstützte. Solche Büchersammlungen wurden in zehn von fünfzehn Pfarreien des gesamten Dekanats festgestellt. Darüber hinaus werden zwei Klosterbibliotheken erwähnt: in Książ Wielki und in Miechów. Die Zahl der Bücher schwankte in den einzelnen Pfarreien zwischen 4 und 98 Bänden. Die Grundlage der Pfarrbibliotheken bildeten vor allem Predigthilfen sowie Literatur aus dem Bereich der Pastoral-, Moral- und asketischen Theologie, was nachdrücklich von ihrem praxisbezogenen Charakter zeugt. Dagegen interessierte sich der Klerus weder für Kirchengeschichte noch für kanonisches Recht. Auch Bibeln, Heiligenviten oder Schriften der Kirchenväter wurden nur selten notiert. Und die in bescheidenem Ausmaß vorhandene weltliche Literatur bildete ausschließlich eine Ergänzung zu den Werken mit religiösem Inhalt. Gelesen wurde vor allem in polnischer und in lateinischer Sprache. Eine Analyse der Daten der Erstausgaben der in den Pfarrbibliotheken des Dekanats Książ Wielki vorhandenen einzelnen Titel erlaubt die Feststellung, dass in ihnen Drucke aus dem 17. Jahrhundert oder ältere dominierten, während nur knapp ein Fünftel aller Titel im 18. Jahrhundert herausgegeben wurde. Das Fehlen neuerer Bücher in den Bibliotheken zeugt davon, dass diese Sammlungen eher eine Art Lager oder Antiquariate darstellten. Man kann lediglich annehmen, dass die bei der Visitation nicht berücksichtigten persönlichen Bibliotheken für die Gestaltung der intellektuellen Kultur der Geistlichkeit vorrangige Bedeutung besaßen.
\end{abstract}

